\title{
THE WALAGARA MARRIAGE RITUAL The Negotiation between Islamic Law and Custom in Tengger
}

\author{
Muh. Fathoni Hasyim | UIN Sunan Ampel Surabaya - Indonesia \\ Liliek Channa AW | UIN Sunan Ampel Surabaya - Indonesia \\ Moh. Mufid | UIN Sunan Kalijaga Yogyakarta - Indonesia \\ Corresponding author: fathoni.hasyim@uinsby.ac.id
}

\begin{abstract}
A dialectic between Islamic law and local custom has been the main feature of Islam in Indonesia. As it is elsewhere, the interplay between local custom of Hindu Tengger society in East Java with Islamic law as ethic-norm of Islam cannot be avoided in the framework of negotiation between the two entities. This article seeks to answer how Tengger marriage ritual of Walagara as the local culture apply to Muslim minority in the region and how Islam as legal norm for Muslims adapts the local custom. This result of the study shows that is Tengger society there has been negotiation and compromise in the application of marriage ritual in Walagara ritual. This ritual is understood symbolically as a tradition that should be preserved and applied by adherents of all religions in the region, which necessitates paradigmatic shift in Tengger society toward the existence of Walagara from a religious ritual to become a mere tradition. Marriage is solemnized based on religion of the bride and groom, hence Walagara ritual is observed. In this regard, the negotiation between Islamic law and local custom is symbolic-substantive which creates a hybrid ritual combining both entities.
\end{abstract}

Keywords: Walagara, marriage ritual, Islamic law, local custom

\section{Introduction}

The study about Islam and Hindu Tengger society in post-Dutch colonialism has been done by many scholars, either Western or Indonesian scholars. Islamic studies-Tengger relation is portrayed in a more general context, namely a study of Islam and local culture. Since 
the beginning, Western scholars such as Geertz ${ }^{1}$, Hefner ${ }^{2}$, Woodward ${ }^{3}$, Mulder, ${ }^{4}$ Zaehner, and Peacock ${ }^{5}$ have researched relationship between Islam and local culture (read: Java). The conclusion of those Western anthropology scholars in viewing "Islam Jawa" or "Javanese Islam" (including relationship between Islam and Tengger Hindu culture) comes into two theses or two main perspectives; (1) Formalist Islam and (2) Substantialist Islam.

Writings on Tengger and its local tradition, including Walagara tradition are also widely circulated. In around the 1980s, there were Robert W. Hefner ${ }^{6}$ and his wife Nancy J. Smith Hefner ${ }^{7}$ who studied Tengger. Other researches were also conducted by local researchers from various disciplines, such as Ridei, ${ }^{8}$ Suyono, ${ }^{9}$ Putri Indah Kurniawati, Ayu Sutarto, ${ }^{10}$ and many more. ${ }^{11}$

1 Clifford Geertz, The Religion of Java (Glencoe: The Free Press, 1960).

2 Robert W Hefner, Hindu Javanese: Tengger Tradition and Islam (Princeton: Princeton University Press, 1985); Robert W Hefner, The Political Economy of Mountain Java: An Interpretative History (California: University of California Press, 1990).

3 Mark R. Woodward, Islam Jawa: Kesaleban Normatif versus Kebatinan (Yogyakarta: LKiS, 1999).

${ }_{4}$ Neil Mulder, Inside Indonesian Society: Cultural Change in Java (Amsterdam: The Pepin Press, 1996).

5 Peacock J., Muslim Puritans: Reformist Psychology in South-east Asian Islam (Berkeley: University of California Press, 1978).

6 Among the published works of Robert W. Hefner on Tengger are "Ritual and Cultural Reproduction in Non-Islamic Java," American Ethnologist, 10, 4 (1983), pp. 665683; Hindu Javanese: Tengger Tradition and Islam (1985), "Masyarakat Tengger dalam Sejarah Nasional Indonesia" with Nancy J. Smith-Hefner (1985), "Japa-Mantra Hindu Kuno dalam Tradisi Tengger" with Nancy J. Smith-Hefner (1985), "The Politic of Popular Art: Tayuban Dance and Culture Change in East Java," Indonesia, 43 (April 1987), pp. 75-94; "Islamizing Java? Religion and Politics in Rural East Java," The Journal of Asian Studies, 46, 3 (1987), pp. 533-554; and The Political Economy of Mountain Java (1990).

7 Nancy J. Smith Hefner also published her researches such as "A Social History of Language Change in Highland East Java," The Journal of Asian Studies, 48, 2 (1989), pp. 257-271; and "Pembaron: An East Javanese Rite of Priestly Rebirth," Journal of Southeast Asian Studies, 23, 2 (1992), pp. 237-275.

8 Mohamad Ridei, "Relasi Islam dan Budaya Lokal: Perilaku Keberagamaan Masyarakat Muslim Tengger di Desa Sapikerep, Kecamatan Sukapura, Kabupaten Probolinggo, Propinsi Jawa Timur," (Unpublished Master Thesis, Graduate program UIN Malang, 2011).

9 Capt. R. P. Suyono, Mistisisme Tengger (Yogyakarta: LKiS, 2009).

10 In addition, Sutarto also wrote second book published in 2002 entitled "Di Balik Mitos Gunung Bromo: Tentang Orang Tengger dan Tradisinya. 
Of those various researches, there is still limited study that specifically discusses Walagara as marriage ritual in its encounter of customary law and Islamic law among Tengger people in Tosari, Pasuruan, East Java. The encounter of two institutions of customary and Islamic law results in an entity that is anchored in the tradition of Tengger people. Walagara tradition as customary marriage ritual of Tengger people and Islamic law as religious norm which is still adhered by Muslim minority necessitates compromise in the context of maintaining own identity, from Walagara as tradition (local custom) and symbolic reception (Islamic law).

For ages, Tengger has become the target of religious mission by Christians and later Muslims. For Islam to be accepted by Tengger people, it should show a stretched degree of flexibility. At this level, Islam as a religion with norms which encounters with local culture is expected to adapt with the situation and context. On the other hand, Walagara tradition which is deeply entrenched in Tengger people, should also be accepted by Muslim minority as a symbol of religious ritual. Therefore, the encounter of the two institutions, culture and religion, in the context of Walagara tradition as local custom and symbolic marriage reception in the perspective of Islamic law becomes an interesting object of study.

This article focuses on the discussion around the encounter between Walagara marriage tradition which is part of Tengger custom and marriage reception in Islamic law as religious ethic-moral. This article will answer question on how marriage ritual in Walagara tradition among Tengger people becomes local culture and applies adherents of all religions, including Muslim minority and how the encounter of Islam as legal norm adapts with local culture. Negotiation model that takes place in Tengger people related to local custom law and Islamic law in maintaining own distinct identity with the approach of the application of Islamic law in Indonesia.

\section{The Accommodation Theory of Islamic Law and Local Custom}

The response of local population toward the spread of Islam in the archipelago has created three types of Muslim community. The first is symbolic-substantive acceptance of Islam. As such, they accepted Islam and abandoned their pre-Islamic custom. The second is

11 Putri Indah Kurniasari et. al., "Potret Sistem Perkawinan Masyarakat Tengger di Tengah Modernitas Industri Pariwisata," Jurnal Solidarity, 1, 1 (2012), pp. 1-4. 
selective with modification in which local community accepted Islam as long as they can fit it to their custom. Thus, when there is contradiction, Islamic aspects will be modified to fit local practices. The third is symbolic acceptance, in which local people accepted Islam as symbol. In such a case, they actually still observed their pre-Islamic custom and belief and considered Islam only as veneer. ${ }^{12}$

The dialectic process between Islamic law and custom in Indonesia needs accommodation to mitigate and neutralize tension among individuals or social groups resulting from different understandings. The purpose of this process is to create synthesis or new pattern. Howard F. Federspiel called this as hybrid culture. ${ }^{13}$ Gillin and Gillin in their research displayed this accommodation process in the field of legal norm. ${ }^{14}$ At this point, as far as the interplay between Islamic law and local custom is concerned, some researches show evidence of integration, synthesis and assimilation. Thus, from the perspective of social dynamics, there is actually no contradiction in this context. In fact, the relationship between custom and Islamic law is accommodative. The position of these two legal entities is equal. They have their own role which is complementary without losing each identity. 15

In many regions before the enactment of Act No. 1/1974 on Marriage, Islamic law and customary law is the point of reference for

12 Abdurrahman Misno Bambang Prawiro, Reception through Selection-Modification: Antropologi Hukum Islam di Indonesia (Yogyakarta: Deepublish, 2016), p. 17; Abu Rokhmad and Sulistiyono Susilo, "Conceptualizing Authority of the Legalization of Indonesian Women's Rights in Islamic Family Law," Journal of Indonesian Islam, 11, 2 (2017), pp. 489-508.

13 Howard M. Federsiel, Sultans, Shamans and Saints: Islam and Muslims in Southeast Asia (Honolulu: University of Hawai Press, 2007), p. 255

14 The process of accommodation is as follows: The first is the establishments of efforts in avoiding the seeds of new conflict for social integration. The second is the suppression on opposition. The third is the realization of coordination or synergy. The fourth is the alteration of social institution to fit with the new achieved state after accommodation. The fifth is the shift in position and role pattern. The sixth is the opening to the occurrence of assimilation which is aimed at mitigating available differences. See, John Lewis Gillin and John Philip Gillin, Cultural Sociology (New York: The MacMillan Company, 1954), p. 517.

15 Jenkins argues: "The power of law as an instrument of order is limited by the very nature of the legal apparatus: this apparatus is admirably adapted to some tasks and functions..." For more details, see Iredel Jenkins, Social Order and the Limits of Law. A Theoretical Essay (Pricenton New Jersey: Pricenton University Press, 1980), p. 313. 
marriages. On the other hand, in sociological speaking there is a socalled competition between Islamic law and customary law because of assumptions that the two have unequal position and different roles. If these assumptions diminish from people's minds, there will no anymore tension. It is because each legal system has its own proportional position and role in governing activities, especially in private aspects of the law. This echoes Jenkins' statements: The power of law as an instrument of order is limited by the very nature of the legal apparatus: this apparatus is admirably adapted to some tasks and functions..."16

Furthermore, Federspiel illustrated that Islam successfully integrated its teaching with local culture by saying:

"So, although Islam was expected to integrate with local custom, often it was local custom that adapted to Islam, so that a dynamic process was set in motion one that was not altogether clear in its direction at this particular juncture. Many of these cultural accommodations were still being worked out in the next era, and the differences between Islam and custom became much more of an issue at that time." 17

The dynamic of Islamic law and custom is still on going. Therefore, each community has its own characteristic in accommodating the two governing entities. This synthesis necessitates collective awareness that the two contribute in providing legal guidance for a multicultural society.

\section{Islam and Tengger People in Tosari, Pasuruan}

In the study of Islamic history in Indonesia, the process of Islamization is a widely debated topic ${ }^{18}$ among historians because of its complexity and interest. ${ }^{19}$ This process the spread of Islam in Indonesia at least results in four theories, ${ }^{20}$ namely: Indian theory, ${ }^{21}$

\footnotetext{
16 Ibid.

17 Federspiel, Sultans, Shamans and Saints, p. 87

18 Mitsuo Nakamura, The Crescent Arises over the Banyan Tree; A Study of The Mubammadiyah Movement in a Central Javanese Town (Yogyakarta: Gadjah Mada University Prees, 1993), pp. 1-2.
}

19 M. C. Ricklefs, Sejarah Indonesia Modern, trans. Dharmono Hardjowidjono (Yogyakarta: Gadjah Mada Universiry Press, 1990), p. 3

${ }^{20}$ Husaini Husda, "Islamisasi Nusantara; Analisis terhadap Discursus Para Sejarawan," Adabiya, 18, 35 (2016), p. 20. 
Arab theory, ${ }^{22}$ Persia theory, ${ }^{23}$ and China theory. ${ }^{24}$ These theories explained the origin of Islam that came to Indonesia with different origins and medium, namely; trade, 25 marriage, Sufism, 26 art performance, ${ }^{27}$ and politics. ${ }^{28}$

These theories only analyze the coming of Islam to Sumatera, especially Aceh, and java. These two islands is believed to have important role in further spreading Islamic to other hinterland islands in the archipelago. ${ }^{29}$ Therefore, in the context of the coming of Islam to Tengger community should be further examined. Tengger people, as explained by Hefner, has distinctiveness among mountain people in Indonesia, even in Southeast Asia. In addition to its long historiography, Tengger is known for its firm commitment in preserving and maintaining its norms, tradition and culture across time. ${ }^{30}$

According to Mujiburrahman that quotes works of Hefner, the significant feature of Mout Bromo, in which Tengger people are located, was its role as an important spiritual shrine for Majapahit Kingdom, a great Hindu Javanese polity in around fifteenth Century. When the influence of Islam started to grow in the following century,

21 G.W.J. Drewes, "New Light on the Coming of Islam Indonesia," in Readings on Islam in Southeast Asia (Singapore: Institute of Southeast Asia Studies, 1983), p. 8.

22 Azyumardi Azra, Islam Nusantara: Jaringan Global dan Lokal (Bandung: Mizan, 2002), p. 28.

23 P. A. Hoesein Djajadiningrat, "Islam di Indonesia" and Kenneth W. Morgan, Islam Jalan Lurus, trans. Abu Salamah and Chaidir Anwar (Jakarta: Pustaka Jaya, 1986), pp. 426-7.

${ }^{24}$ H.J. de Graaf, et al., China Muslim di Jawa Abad XV dan XVI; Antara Historitas dan Mitos, trans. Alfajri (Yogyakarta: Tiara Wacana Yogya, 1998), p. 101.

25 Ahmad Al-Usairy, Sejarah Islam, Sezak Zaman Nabi Adam Hingga Abad XX (Jakarta: Akbar Media, 2003), p. 336.

26 The arrival of Sufís in Indonesia is estimated to take place mainly since the $13^{\text {th }}$ century CE when the spread of Sufís from Persia and India took place. The most apparent growth of Sufism was in Sumatra and Java, which was the $16^{\text {th }}$ and $17^{\text {th }}$ Century CE. See Uka Tjandrasasmita (ed.), Sejarah Nasional Indonesia III (Jakarta: PN Balai Pustaka, 1984), p. 218.

27 Badri Yatim, Sejarah Islam di Indonesia, (Jakarta: Depag, 1998), p. 202.

28 Ibid., p. 206.

29 M. C. Ricklefs, Sejarah Indonesia Modern, p. 74.

30 Robert W. Hefner, Geger Tengger: Perubahan Sosial dan Perkelaian Politik (Yogyakarta: LKiS, 1999), p. xxii. 
the highland of Bromo was remained untouched. Even if there was Muslims in this period, they are considered nominal Muslims with less commitment to Islamic orthodoxy. During Dutch colonialism, Tengger was target of Christian Mission, but the conversion to Christianity was minimal until the influx of Muslim farmers and traders in lowland that close to Tengger. In the early twentieth century more Muslims migrated to the area, especially Madurese working for coffee plantation. ${ }^{31}$

During the so-called Old Order period (1959-1965), prior to Communist coup d'état attempt in 1965, religion of Tengger people was called Budo (Javanese Hindu). Interestingly, Muslims in lowland (ngare) came up with this term to designate the religion of Tengger people. This term was used to indicate that they are not Muslims. Moreover, lowlanders considered them as infidels. As quoted by Burhani from Hefner, Tengger people is best termed as Kejawen because they admit their Islamic identity with heavy emphasis on the significance of Javanese custom which is not necessarily condoned by Islamic orthodoxy. 32

The shift on the system of belief of Tengger people took place during the New Order period (1967-1998) as the regime launched religion formalization with an enactment of Presidential Decree No. $1 / 1965$ on the prevention of religious blasphemy. Basically, with this policy the state only recognized five religions; Islam, Christianity, Catholicism, Hinduism and Buddhism. The new order regime made use this Old Order policy to launched control over beliefs of the people. The aim of the regime on this control policy was to corporately demand obedience of citizens in accepting national policies and programs. ${ }^{33}$ Tengger people had to choose one of these five religions as their religion. Many of whom became Hindus, but some opted Islam and Christianity. The success of formulating the belief of Tengger people became the legitimate space for the regime in implementing religious education. For Tengger, it was mainly Hindu education. Starting 1979, the east Javanese office of religious affairs,

\footnotetext{
31 Mujiburrahman, "Religious Conversion in Indonesia: The Karo Batak and the Tengger Javanese," Islam and Christian-Muslim Relations, 12, 1 (2001), pp. 26-27

32 Ahmad Najib Burhani, "Geertz's Trichotomy of Abangan, Santri, and Priyayi: Controversy and Continuity," Journal of Indonesian Islam, 11, 2 (2017), pp. 329-350.

33 Ali Maksum, "Politik Identitas Masyarakat Tengger dalam Mempertahankan Sistem Kebudayaan dari Hegemoni Islam dan Kekuasaan," el-Harakah, 17, 1 (2015), p. 21.
} 
the ministry that has the authority on religious education, sent two religious teachers to Tengger, Hindu teacher and Islam teacher.

In this context, the campaign of Tengger Islamization started in Tosari Pasuruan. It was implemented intensively, and not long after that, a mosque was established in the village. Prior to that, KH. Ahmad Dahlan, the founder of orthodox Islamic organization of Muhammadiyah once performed da'wa to Tengger people in the area of Bromo mountain slope. Therefore, it was not a surprise that Muhammadiyah existed in Tosari quite early. ${ }^{34}$ Tension was recorded between Javanese Hindus and orthodox Muslims with the result of eradication of Javanese rituals and aesthetic traditions in the areas dominated by Muslims. ${ }^{35}$ However, Muhamadiyah branch was only established in Tosari officially in 2014, as a Muhammadiyah's contribution to enlightening Tengger people of Tosari Pasuruan. ${ }^{36}$

Other Muslim organization also took part in the process, such as Nahdlatul Ulama, and its affiliated pesantren and ulama. In formal matter, the Nahdlatul Ulama MWC functionaries of sub-district Tosari was established in 1992. The involvement of Nahdlatul Ulama in Tengger marks another chapter in the process of Islamization due to its accommodative stance to local culture. It is quite safe to say that Islam came to Tengger people of Tosari Pasuruan through peaceful da'wa. Among the preachers of this peaceful process were the charismatic KH. Abdul Hamid Pasuruan and KH. Abu Amar Pasrepan Pasuruan. These two ulama frequently visited Tosari, which also known as brang kulon (Western side of Tengger), for preaching. The waves of Tengger Islamization happened in several phases: firstly, the phase of marriage between Muslims from Pasuruan and Tengger women of Tosari. The marriage ritual was conducted in Islamic way as well as local custom. These newcomers were warmly welcomed by the

\footnotetext{
34 James L. Peacock, Gerakan Muhammadiyah Memurnikan Ajaran Islam di Indonesia (Jakarta: Cipta Kreatif, 1986), p. 24.

35 Mujiburrahman, "Religious Conversion in Indonesia: The Karo Batak and the Tengger Javanese," p. 27.

36 Luqman Wahyudi, "Pendidikan Multikultural di Masyarakat Tengger Tosari Pasuruan (Studi Gerakan Pencerahan Muhammadiyah Tosari Pasuruan)," Adabiyah Jurnal Pendidikan Islam, 2, 1 (2017), pp. 121-134.
} 
locals. Among early Muslims who married with Tengger women of Tosari were Kholil, Moh. Suhud, Sukardi, Wajik, Thahir, and Matajir. ${ }^{37}$

Second phase of Tosari Islamization process still used marriage channel. Among second Muslim generation who migrated to Tosari and married local women were Basori Alwi, Anshori, Trisno Sudigdho and some others although some did not stay in Tosari. They later were and are active in local office of Nahdlatul Ulama. Subsequent phase was a massive da'wa by sending santri (Muslim students) who freshly graduated from pesantren affiliated to Nahdlatul Ulama to Tosari to teach Islam. In addition, the momentum of the returning Tosari Muslim students who finished their Islamic education in several pesantren in Pasuruan also marked a significant deal in this process. ${ }^{38}$

Some pesantrens that contributed in sending their students to preach in Tosari starting 1990a until now are Pesantren Arghab Pasuruan, Pesantren Besuk, Pesantren Salafiyah led by KH. Idris Hamid, and Pesantren Sunni Salafiyah led by Habib Taufiq Assegaf. The success of the preaching is marked by the establishment of a mosque in every village in Tosari. ${ }^{39}$

In 1993-1994, an Islamic foundation established by Suharto's New Order regime, called Amal Bhakti Muslim Pancasila also built a mosque named al-Mujahidn in Tosari. Later in 2003, Muslim business community of Pasuruan also built a mosque named Attaqwa in Ngadirowo. Also, the fund from Saudi Arabia was sought by Habib Taufiq to build many mosques, namely in Podokoyo village, Sedaeng village, Baledono village and others. ${ }^{40}$ Nowadays, mosques are the center for da'wa of Islam among Tengger people in Tosari Pasuruan.

Nowadays, according to a statistic in 2018 in Tosari district there are about 18.843 people of which 6.461 are Muslims, 12.222 are Hindus, and 160 are Christians. However, although the number of Hindus are as twice as much, from the eight villages in the area,

\footnotetext{
${ }^{37}$ Interview with Trisno Sudigdho (the Chairman of Tanfiziyah, MWC NU Tosari, Pasuruan), September 26, 2019.

38 Ibid.

39 Interview with Basori Alwi (the Chairman of Syuriah, MWC NU Tosari, Pasuruan), September 27, 2019.

40 Ibid.
} 
Muslims are majority in four villages, whereas in the rest four villages Hindus are majority. ${ }^{41}$

\section{Walagara Marriage Custom among Tengger People}

Tengger society is characterized as people who live in peace and harmony. The emphasis on peace and harmony is very strong in Tengger. They have philosophy of life that shows their peaceful life, namely Anteng Seger, which means peace and prosperity. There is also a slogan used to reflect their unwillingness to debate and quarrel, namely "sepi ing gunem, rame ing gawe" which literally means talk less, do more. ${ }^{42}$ Any issues that might harms peace and harmony, like politics and religious plurality, is strictly avoided in public conversation.

For that peace loving rationale, Tengger marriage used to be endogamous. It means that they marriage within Tengger social group. They were not allowed to marry non-Tengger. However, this system is no longer observed because of many considerations. ${ }^{43}$ Now, Tengger marriage is considered exogamy and heterogamy with no restriction to marry people from other group with different social level even people from outside Tengger. ${ }^{44}$ Nonetheless, Tengger women who choose to marry men from different region or outside Tengger social group must still observe Tengger custom and stay in Tengger region. If a woman chooses to stay with her husband in his place, then the woman is considered to give up her membership as Tengger people. ${ }^{45}$

Customary marriage ceremony of Tengger people is known as Walagara. Etymology speaking, the term is from from Sanskrit language, consisting two words of wala which means child, and gara which means marriage. Thus, the combined term of Walagara denotes

41 Harwan Dharma Aji Manggala, "Perubahan Sosial di Tosari; Studi Kasus Lunturnya Folklore Masyarakat Desa Tosari, Kecamatan Tosari, Kabupaten Pasuruan," Indonesian Journal of Sociology, Education and Development, 1, 2 (2019), p. 18.

42 Okta Hadi Nurcahyono, "Social Capital of Indigenous Village Communities in Maintaining Social Harmony; Case Study of The Tenggerese Indigenous Community, Tosari, Pasuruan East Java," Advances in Social Science, Education, and Humanities Research, Volume 313, International Conference on Rural Studies in Asia (ICoRSIA 2018), p. 161.

43 Interview with Riyadi, dukun of Tosari village, September 27, 2019.

44 Jazim Hamidi, Hukum Perkawinan Campuran (Eksogami) ala Masyarakat Hukum Adat Tengger (Malang: Universitas Brawijaya Press, 2014), p. 22.

45 Putri Indah Kurniawati et. al., "Potret Sistem Perkawinan Masyarakat Tengger di Tengah Modernitas Industri Pariwisata," Jurnal Solidarity, 1, 1 (2012), p. 3. 
marriage ceremony of Tengger people. Terminologically, Walagara means a marriage between a man and woman with the goal of building a harmonious family as legitimate husband and wife. ${ }^{46}$ Without this customary Walagara ritual, a marriage of Tengger couple will be deemed customarily illegitimate.

In the past, especially prior 1965 , Walagara was the only marriage ceremony for Tengger people. This customary ritual determined the legitimacy of marriages for Tengger people. Nonetheless, nowadays Walagara is not enough in providing legitimacy for their marriages. Any marriage which is conducted with customary Tengger tradition has to be registered in Marriage registration office from Muslims and Civil Registry office for non-Muslims. Thus, marriage legitimacy not only conditional to observance of Walagara ritual, but also requirement of formal religion observed by Tengger people. For many Muslims in Tengger, observing Walagara is now a matter of honoring tradition, not religious obligation as they believe that marriage should be solemnized in Islamic way. This conviction happens to be endorsed by the state.

On the other hand, certain Tengger people who still firmly observe tradition are convinced that observing Walagara ritual is an essential norm of being Tengger people, whereas observance of religious marriage ceremony is a matter of formality in satisfying the state requirements. ${ }^{47}$ Riyadi, a Tengger man says:

"Walagara ritual is practiced as the expression of gratitude to God, upon the realization of marriage and also a means for asking for blessing to relatives, friends, local community, and ancestors who are still alive and those who have passed away. Also to the pepunden (ancestors' holy tombs) and danyang kang mbaurekso (a spiritual figure who protects and guards) the village to give blessing, so that the marriage will last forever in harmony, peace and prosperity. However, marriage legitimacy is still conditional to religion of the bride and groom, as it is required by the state." 48

Prior to this Walagara ritual, religious solemnization is conducted. This Walagara ritual is conducted afterwards, either in the same day or

\footnotetext{
46 Suyitno, Mengenal Masyarakat Tradisional, Masyarakat Suku Tengger (Malang: SIC Group, 2001), p. 75.

47 Interview with Riyadi, dukun of Tosari village, September 27, 2019.

48 Ibid.
} 
the following day(s). For Muslims, this solemnization is conducted either in the house of the bride's parents with the presence of marriage registrar from the Office of Religious Affairs as required in Islamic family law. Alternatively, Islamic marriage solemnization is conducted in the Office of Religious Affairs with the presence of the concerning parties, namely the bride, her guardian, the groom, two male witnesses, and the marriage registrar.

The ritual of Walagara marriage ritual is divided into three phases, preparation, including searching for suitable match, determining date of marriage using Tengger calendar, and continued with proposal process. This proposal process involved parents of both bride and groom. The date of marriage solemnization of Tengger people is determined by the date calculation by dukun pandhita (spiritual elder) by taking account the Saptawara or Pancawara of the bride and groom. ${ }^{49}$ The idea is that the certain dates will bring good luck, whereas others will bring bad luck to the couple and the family. The dukun also uses fate calculation based on sandang (clothes), pangan (food), and lara (illness), and pati (death). If the marriage ceremony happens to be arranged in the date of illness or death, the couple must conduct ngepras ritual. It is an offering which has been supplied with mantra (mystical chanting) by the dukun then to be sacrificed to avoid misfortune. To remain safe and secure, couples whose marriages happen to take place in the date of illness or death must conduct ngepras ritual every year. ${ }^{50}$ The ritual consists of pasrah manten (bride and groom entrustment), temu manten (the meeting of bride and groom), jopomantra (mystical chanting and supplication), pemberkahan (blessing) and sembaban (honoring the parents), pangkon (lapping the

\footnotetext{
49 Saptawara is the name of a week consisting of 7 days observed in Javanese and Balinese culture. While Pancawara is the name of a week consisting of 5 days observed in Javanese and Balinese culture. Pancawara is also called pasaran (market) day in Javanese. This market day is derived from the name of traditional market in the past that opened only on certain days, namely Pasar Legi, Pasar Paing, Pasar Pon which open on the designated market day. See, Zoetmulder, Kamus Jawa Kuna-Indonesia (Jakarta: PT Gramedia Pustaka Utama, 1995), pp. 751, 755, 1033, 1389. Another term used for calculating birth day of the bride and groom is called "weton" (birthday)

50 Ayu Sutarto, Sekilas Tentang Masyarakat Tengger, (paper), delivered on the briefing of culture exploration 2006 organized by Balai Kajian Sejarah dan Nilai Tradisional Yogyakarta, August 7-10, 2006.
} 
bride by the groom) or peturon penganten (laying down in bed), nduliti (touching the bride) and lastly a ritual called banten kayoban agung. ${ }^{51}$

The Walagara ritual is accompanied by several traditional Javanese art performance. Gamelan ensemble is often performed. In the past, the performance was accompanied with female dancers (waranggono) with Tayub Mbeso dance which attracted male audience to dance along. Afterwards, wayang kulit (Javanese puppet show) was performed until dawn of the following day. Nowadays, though, the performances were scarcely shown. They are replaced by Dangdut musical performance, an Indonesian popular music for dancing that combines local music traditions, Indian, Arabic and Malaysian film music.

This Walagara ritual is led by spiritual elder called dukun pandhita. For Tengger people, dukun pandhita is not a paranormal nor healer as it is so in Javanese culture. Instead, dukun pandhita is a term used by Tengger people to denote a holy and highly consecrated person. dukun pandhita plays crucial role in customary rituals in Tengger, namely marriage, death, and other rituals and events. The position of dukun pandhita is much respectable compared to modin (lower religious functionary) among Muslims in Java, but lower that pedanda in Balinese Hindu people. The inauguration of dukun pandhita in Kasada celebration starts from long process which has to be experienced by the candidate of dukun pandhita. Among the process is learning and memorizing archaic and complex texts in japa mantra script used in rituals of Tengger people. Traditionally, Tengger people who are entitled to become dukun pandhita are Hindus. However, this condition is relaxed as there is a Muslim dukun pandbita now in Tosari sub-region.

In Tosari Tengger villages, Muslim Minority and Hindus lives without geographical borders. They live peacefully regardless religious affiliation. They help each other in almost all aspects of their lives. There was once an occasion when a Hindu Tengger donated a piece of land for construction of a mosque for their Muslim neighbors. Arguably, being Tengger people is the glue of this harmonious life. In the event of Walagara rituals, they all contribute to Walagara in one way or another. Muslims have the role for slaughtering the cattle and poultry, while Hindus prepares the nitty gritty of the ritual such as incense, performs as dukun and pranatacara (master of ceremony). Like

51 Sri Wakhyuningsih, "Nilai-Nilai Moral Pada Upacara Perkawinan Adat Walagara Masyarakat Suku Tengger di Desa Jetak Kecamatan Sukapura Kabupaten Probolinggo," (Upublished undergraduate thesis, Universitas Negeri Malang, 2007), p.3 
Hindu Tengger people, Muslims also hold Walagara ritual and attends it, except more orthodox Muslims living in the eastern part of Tosari who refuse in participating Tengger traditional rituals like Walagara and Kasada.

\section{The Accommodation of Custom and Islamic Law in Walagara Marriage Ritual}

Negotiation is a strategy for bargaining used by Tengger people to stay committed in observing their custom amidst various modern forces which in some encounters with Tengger custom becomes very threatening. Negotiation strategy is a soft method in facing major forces outside itself. For Tengger people, negotiation is a strategy to combine religious norms and custom. This combination is also deployed as a strategy to protect custom practices, including rituals surrounding marriage practices with Walagara custom in Tengger.

They do this in order to detach the practice of custom rituals from religious arguments. Some Tengger leaders argue that some Tengger rituals do have strong religious legitimate basis. By arranging such a position, religion actually does not have enough excuse for throwing away customary values of Tengger. Thus, the power of formal religion will tolerate the observance of customary rituals as they are without having to "civilizing" or "orthodoxing" the values of Tengger custom. At this point, the Walagara ritual is merely a customary symbol that its existence must be preserved.

The adoption of exogamy over endogamy further highlights this point. Traditionally, endogamy practices is observed to maintain class structure. In the Nineteenth Century England, for example, social endogamy or endogamy by social class as Leuween and Maas called in, was observed. It was a marriage within the same class or marriage of approximately the same status. ${ }^{52}$ In Tengger, however, endogamy meant another thing. It was not to preserve this class structure, but to preserve and safeguard the Javanese tradition of Tengger. Moreover, like virtually all other traditional groups in Indonesia, there was no social class or status in Tengger. What happens in Tengger is the diminishment of endogamous marriages due to modernity. Similar cases happened across Asia as modernity and education made people aware that endogamy, especially marriage between cousins, causes

52 MHD Van Leeuwen, Ineke Maas. "Endogamy and Social Class in History: An Overview," International Review of Social History, 50, S13 (2005), pp. 1-23. 
health issue. ${ }^{53}$ The diminishment is also attributed to media exposure and technology. As Dukun Suparman said, Tengger people now may marry non-Tengger people, because Tengger people increasingly interact with non-Tengger people in several ways, especially starting the New Order corporative regime. In the past, Tengger were selfsufficient. They are farmers and all of the farming products are for fulfilling own needs. They grow potatoes, cabbages, carrots, leeks, etc. Later, as surplus increased, farmers started to sell it to non-Tengger people which required them in towns nearby and beyond. Moreover, there are increasingly more number of Tengger people who work in public services like teachers in public schools and bureaucrats. They start to build an awareness that they are not only identified themselves as Tengger, but also as Indonesians. All of these factors contribute to gradual diminishment of endogamy from Tengger people. They now are allowed to marry non Tengger people regardless tribe, custom and even religion.

Another negotiated result is the cattle and poultry slaughter for the Walagara ritual. As elsewhere, food is an integral part of any traditional rituals. It often involves sacrifice and food offering. ${ }^{54}$ In the past, Tengger people used to slaughter buffalo for major customary event like Walagara. Nowadays, though, this notion is relaxed as people may slaughter cows, goat or chicken. For Walagara, they slaughter cattle and poultry for the dish, after being blessed by dukun pandhita. However, Muslims do have set of regulation related to slaughtering animal. Failing to meet the requirements, the food is not halal (not allowed) for consumption. It has to be slaughtered by Muslims or at least by people of the book (Jews of Christians). In addition, it has to be performed using certain procedures by cutting the throat: that is cutting the trachea and esophagus and the jugular veins. It is usually used for sheep, cattle and poultry. ${ }^{55}$ This requirement is indispensable for Muslims. Thus, the slaughter of Hindu Tengger person is deemed not

\footnotetext{
53 Samia Imtiaz et. al, "Social Change, Modernity and Endogamous Marriages: Anthropological Analysis," Science International, 27, 1 (2015), p. 695.

54 See for instance, Ruth Illman and Bjorn Dahla (eds), Religion and Food (Turku/Abo: Aboprint, 2015), p. 7.

55 Zeiad Amjad Abdulrazzak Aghwan, "Ritual and Traditional Slaughter Practices for Meat Production," Journal of Islamic, Social, Economics and Development (JISED), 14, 19 (2019), pp. 224-230.
} 
halal. The only way for making this to happen is letting the Muslims slaughtering the cattle and poultry.

This solution means two things. The first is the perseverance of Walagara ritual by all elements of Tengger people. This means a lot for them, since they uphold peace and harmony in all aspects of life. The reluctance of Muslims in eating food of rituals would undermine the very essence of Tengger identity. The ritual should be attended and joined by all who considered Tengger. This brings to the second point, which is the inclusion of Muslims as Tengger people regardless their religious conviction. It also a confirmation that Tengger rituals, including Walagara is a matter culture and tradition, not religious teachings. Thus, this also gives way for Muslims in not only attending the rituals, but also participating and even organizing such rituals for themselves. Certainly, not all Muslims have such assumption. More orthodox Muslims in the area refused to attend, participate and organize such rituals due to their more puritanical stance of Islamic dogma.

Another sign of negotiated form is the relaxed requirement of being dukun pandhita, the highest cultural position in Tengger tradition. At the moment, there are a few Muslims in the position which is traditionally considered the epitome of Javanese Hindu belief. For Tengger Muslims, this choice is apparently taken for two reasons. The first is the belief among Muslims in Tengger that being dukun pandhita does not contradict their Islamic conviction. The second is that there are many Islamic rituals which are best performed by a person who, in the context of Tengger, is also assumed as dukun pandhita. In addition to be well-versed in Tengger's Japa Mantra, a Muslim dukun is in charge of leading Islamic rituals for his fellow Tengger muslims, such as funeral and tablil (supplication for the deceased). According to $\mathrm{Ki}$ Dukun Suparman, the head of dukun for Pasuruan district, among the 48 dukun pandhita in Tengger who scatter in four districts of Pasuruan, Probolinggo, Lumajang and Malang, there are 2 Muslim dukun pandhita. There are 16 dukun pandhita in Tosari..$^{56}$

In religious practices displayed by Muslim community of Tengger in Tosari Pasuruan, there are some significant identification. Firstly, dukun pabdhita as customary leader, as a religious leader, are invited and involved in Islamic celebrations. Secondly, Muslims also participate in

56 Interview with Riyadi, dukun of Tosari village, September 27, 2019. 
customary Tengger rituals, such as Walagara, Karo, Kasodo and others. Thirdly, the tribute to macrocosms as symbolized by Mount Bromo is also preserved by Muslim community of Tengger.

In the context of marriage ritual of Walagara in Tosari Pasuruan, the tradition is still deeply rooted within Tengger people. This notion applies regardless of religious persuasion. Moreover, some claims that this ritual is a necessity of every marriage solemnization. This shows that Walagara ritual is s very strategic for Tengger people in the context of maintaining their identity.

At this point, Islam as the religions of outsider tries to adapt with the established tradition. Therefore, Tengger Muslim minority conduct the ritual to gaining legitimacy among Tengger people in the marriage ceremony. The compromising attitude is sought by exponents of Islamic law toward local custom is driven by the fact that in real life, Indonesians never cease exercise practices originating from custom. ${ }^{57}$

Nevertheless, the negotiation between customary and Islamic law keeps happening. The two mutually influence each other to maintain their existence. Tengger people as a community negotiates to maintain local culture and tradition which is the heritage of ancestors. On the other hand, Islam blends in tradition as a religious doctrine which is inclusive to local culture and therefore guarantees legal flexibility for integration into social institution which has been deeply rooted in the society.

The Islamic character and feature practiced by Tengger Muslim minority people among the majority Hindu Tengger people are actually identical to other Javanese Muslims in other places. As Woodward puts it, the syncretic life of Javanese Muslims is the amalgamation of local tradition of Hinduism-Buddhism. Woodward's research shows that Islamic tradition in Java (Yogyakarta Court) displays the cunning of Islam in influencing Javanese people. He believes that what happened between Islam and Javanese tradition was not merely cultural acculturation for the purpose of da'wa strategy. ${ }^{58}$ The acculturation that took place in Java did not erase the basic element of Islamic teachings. The basic characteristic of Islamic teaching in its spread was marked by the respect toward local tradition and culture. As Islam in its initial period in Java generally courteous toward local practices that

57 Ratno Lukito, Pergumulan antara Hukum Islam dan Hukum Adat di Indonesia (Jakarta: INIS, 1998), pp. 84-85.

58 Woodward, Islam Jawa, pp. 123-34. 
were widely adhered. Similar phenomenon happened in the relationship and encounter between Islam and Tengger people in Tosari Pasuruan.

At this point, custom and culture become inseparable identity from the life of Tengger people. On the other hand, religion tries to adapt with cultural context of the people with certain flexibility. Islam as a flexible religious doctrine successfully adapts with its surrounding. ${ }^{59}$ The basic character of Islam, which is flexible makes Islam capable of accommodating numerous forms and kinds of social situation. The presence of Islam as universal values in a region does not necessarily deconstruct the already established values in a certain community. These widely held values then are subordinated into Islamic teaching. The values that corresponds with Islam gain appreciation and become part of Islamic expression. Meanwhile, those that are contradictory to Islamic doctrines, such as paganism, are gradually eradicated with elongated evolution system. ${ }^{60}$

The character of Javanese Islam in one side and local tradition which has been long time embedded in the life of Javanese people in other side shows a harmonious dialectic. This dialectic between Islam and local culture produces two different conclusions; syncretic Islam and cultural (substantial) Islam. The encounter between Islam and local culture shows its dialectic without missing each essential element.

This thesis corresponds with Marshall G. S. Hodgson's idea in his work The Venture of Islam, in which he proposes theory of the spread of Islam into three categories, namely: Islamics, Islamicate and Islamdom. By Islamics means a situation when the emphasis is purely dogma without addressing cultural dimension. By Islamicate means there is an intensive encounter and cultural dialog between the message carriers and the recipients. By Islamdom means the spread of Islam through political means, through kingdom, empire, military and power. ${ }^{61}$ For Hodgson, the process of Islamization in the archipelago is actually Islamicate. It is a very intricate process. It means that the process of

\footnotetext{
59 Arif Fikri, "Flekesibilitas Hukum Islam dalam Perubahan Sosial," Asas Jurnal Hukum Ekonomi Syariah, 11, 2 (2019), p. 151.

${ }^{60}$ Fachry Ali and Bahtiar Effendi, Merambah Jalan Baru Islam; Rekonstruksi Pemikiran Islam Indonesia Masa Orde Baru (Bandung: Mizan, 1986), p. 32-4.

${ }^{61}$ See Marshall G. H. Hodgson, "The Venture of Islam: Conscience and History in World Civilization," Volume One, The Classical Age of Islam (Chicago: The University of Chicago Press, 1974), pp. 56-62.
} 
cultural work involves various social-cultural and economic elements. Those elements interact and form a complex network in which readily culture and social space is momentously employed by religious works. Therefore, Hodgson interprets Islamicate as "... something that would refer not directly to the religion, but to the social and cultural complex historically associated with Islam and the Muslims, both among Muslims themselves and even found among non-Muslims." 62

Therefore, the encounter of culture and religion is an inevitability in the dynamics of religious community. Custom and Islamic law as an instrument of social institution that governs social-cultural life of the society necessitates compromise and negotiation for the survival and existence. The two equal entities, religion and culture, mutually influence and are complementary. The result is a Tengger people, consisting of Muslim minority and Hindu majority, who are peaceful and harmonious in the multicultural framework.

Considering the typology of Islamic acceptance of Islam in Indonesia, what happens in Walagara ritual of Tengger is tentatively a new form of typology that synthesizes symbolic acceptance with a modification of certain aspects, ${ }^{63}$ in which shift of values take place among Tengger people. In such a shift, Walagara ritual is a mere symbol and formality. It is maintained in marriage ceremony a cultural identity, not as sacred religious ritual. Meanwhile, Islam as a religious doctrine is accepted as part of social cultural interaction and spiritual piety in the context of sacred ritual.

The interplay between Islamic law and custom in Tengger also exposes the third actor in the equation, the state. This is the because of the development campaign of the New Order regime to corporate all elements of Indonesian citizens. All citizens must remain under control of the state to make development success. This includes its policy on religion. Each Indonesian citizen must fall into a category of recognized religion of either Islam, Christianity, Catholicism, Hinduism, and Buddhism. And being peace loving people, Tengger people tried their best to avoid any confrontation with the state. The desire of Tengger people for having formal religion as recognized by

62 Ibid.

63 As previously explained, there are three typologies of acceptance of Islamic law, they are symbolic-substantive (people accept Islam and abandon their tradition), selective-modified (people accept Islam with adaptation toward their custom), and symbolic (they accept Islam as a symbol). 
the state has become dilemma for them. At this point, Tengger people tries to remain survive and maintain their traditional values and custom. The adoption of formal religion is a matter of inevitability. In addition to social interaction processes, in the context of certain religion like Hinduism, there is state intervention which seems to be dominant, either directly or indirectly. Likewise, Islam also poses the same influence to Tengger people. This dynamic necessitates Tengger people to doing what is necessary to maintain and preserve their identity as Tengger people. They do so through negotiation. ${ }^{64}$ This exactly what they did with Islam in Walagara ritual.

\section{Conclusion}

Walagara tradition as local custom of Tengger people is a marriage ritual that is compulsory for all Tengger people regardless their religious persuasion who wish to get married. This tradition is an identity of Tengger people although there is a shift in interpreting the meaning of the ritual among them. For Muslim minority, they have successfully adapted this tradition with a degree of flexibility.

The encounter of local custom and Islamic law necessitates compromise in preserving local culture of Tengger people in one side, and the ability and willingness for adaptation of Islamic law toward symbolic Walagara ritual. Islam as the religion of newcomers happens to have the ability to adapt the situation. Islam successfully emphasizes harmonization of religious doctrine to local culture. The symbolic interpretation toward Walagara tradition from Muslim minority has been cunningly conducted in gaining ground among Tengger people.

In the context of the application of Islamic law in Indonesia, what happens in Tengger of Tosari Pasuruan is the" melting" of Islamic law in local tradition and taking root in the hearts and minds of Tengger people. Muslim minority are welcomed by Tengger people because of their accommodation of local custom in form of Walagara tradition, which eventually underwent shift to become s mere symbolic. The negotiation of Islamic law and custom is unfolded to maintain each existence in the context of harmonious co-existence. []

${ }^{64}$ Ali Maksum, "Politik Identitas Masyarakat Tengger dalam Mempertahankan Sistem Kebudayaan dari Hegemoni Islam dan Kekuasaan," el-Harakah 17, 1 (2015), p. 23. 


\section{References}

\section{Books and Articles}

Aghwan, Zeiad Amjad Abdulrazzak "Ritual and Traditional Slaughter Practices for Meat Production." Journal of Islamic, Social, Economics and Development (JISED), 14, 19 (2019), pp. 224-230.

Al Usairy, Ahmad. Sejarah Islam, Sezak Zaman Nabi Adam Hingga Abad XX. Jakarta: Akbar Media, 2003.

Ali, Fachry and Bahtiar Effendi. Merambah Jalan Baru Islam; Rekonstruksi Pemikiran Islam Indonesia Masa Orde Baru. Bandung: Mizan, 1986.

Azra, Azyumardi. Jaringan Ulama: Timur Tengah dan Kepulauan Nusantara Abad XVII dan XVIII. Bandung: Mizan, 1999.

--------. Islam Nusantara: Jaringan Global dan Lokal. Bandung: Mizan, 2002.

Benda, Harry J. The Crescent and The Rising Sun: Indonesian Islam Under the Japanese Occupation 1942-1945. Bandung: W. Van Hoeve, 1958.

Burhani, Ahmad Najib. "Geertz's Trichotomy of Abangan, Santri, and Priyayi: Controversy and Continuity." Journal of Indonesian Islam, 11, 2 (2017), pp. 329-350.

Djajadiningrat, P.A. Hoesein. "Islam di Indonesia" and Kenneth W. Morgan. Islam Jalan Lurus, trans. Abu Salamah and Chaidir Anwar. Jakarta: Pustaka Jaya, 1986.

Drewes, G.W.J. "New Light on the Coming of Islam Indonesia" in Readings on Islam in Southeast Asia. Singapore: Institute of Southeast Asia Studies, 1983.

Federsiel, Howard F. Sultans, Shamans and Saints: Islam and Muslims in Southeast Asia. Honolulu: University of Hawai Press, 2007.

Fikri, Arif. "Fleksibilitas Hukum Islam dalam Perubahan Sosial." Asas Jurnal Hukum Ekonomi Syariah, 11, 2 (2019), pp. 147-157.

Geertz, Cliford. The Religion of Java. USA: The Free Press, 1960.

Gillin, John Lewis and John Philip Gillin. Cultural Sociology. New York: The MacMillan Company, 1954.

Graaf, H.J. de, et.al., China Muslim di Jawa Abad XV dan XVI; Antara Historitas dan Mitos. trans. Alfajri. Yogyakarta: Tiara Wacana Yogya, 1998. 
Hamidi, Jazim. Hukum Perkawinan Campuran (Eksogami) ala Masyarakat Hukum Adat Tengger. Malang: Universitas Brawijaya Press, 2014.

Hefner, Robert W. Hindu Javanese: Tengger Tradition and Islam. Princeton: Princeton University Press, 1985.

-------. The Political Economy of Mountain Java: An Interpretative History. California: University of California Press, 1990.

--------. Geger Tengger: Perubahan Sosial dan Perkelaian Politik. Yogyakarta: LKiS. 1999.

Hudgson, Marshall G. H. "The Venture of Islam: Conscience and History in World Civilization." Volume 1, The Classical Age of Islam. Chicago: The University of Chicago Press, 1974.

Husda, Husaini. "Islamisasi Nusantara; Analisis terhadap Diskursus para Sejarawan." Adabiya, 18, 2 (2016), pp. 17-29.

Illman, Ruth and Bjorn Dahla (eds). Religion and Food. Turku/Abo: Aboprint, 2015.

Imtiaz Samia et.al. "Social Change, Modernity and Endogamous Marriages: Anthropological Analysis." Science International, 27, 1 (2015), pp. 697-697.

Irmawati. "Teori Belah Bambu Syahrizal Abbas: Antara Teori Reception in Complexu, Teori Receptie dan Teori Receptio A Contrario." Petita, 2, 2 (2017), pp. 119-130.

Jenkins, Iredel. Social Order and the Limits of Law. A Theoretical Essay. Pricenton New Jersey: Pricenton University Press, 1980.

Kamsi. "Pergumulan Politik Hukum Perkawinan Islam dan Adat di Indonesia." Asy-Syir'ah Jurnal Ilmu Syariah dan Hukum, 46, 2 (2012), pp. 451-476.

Lev, Daniel S. Islamic Courts in Indonesia: A Study of the Political Bases of Legal Institutions. Berkeley: University of California Press, 1972.

Lukito, Ratno. Pergumulan antara Hukum Islam dan Hukum Adat di Indonesia. Jakarta: INIS, 1998.

--------. Hukum Islam dan Realitas Sosial. Yogyakarta: Fakultas Syari ah UIN Sunan Kalijaga, 2008.

Maksum, Ali. "Politik Identitas Masyarakat Tengger dalam Mempertahankan Sistem Kebudayaan dari Hegemoni Islam dan Kekuasaan.” el-Harakah, 17, 1 (2015), pp. 18-35. 
Manggala, Harwan Dharma Aji. "Perubahan Sosial di Tosari; Studi Kasus Lunturnya Folklore Masyarakat Desa Tosari, Kecamatan Tosari, Kabupaten Pasuruan." Indonesian Journal of Sociology, Education and Development, 1, 2 (2019), pp. 13-21.

Mohamad Ridei. "Relasi Islam dan Budaya Lokal: Perilaku Keberagamaan Masyarakat Muslim Tengger; Di Desa Sapikerep, Kecamatan Sukapura, Kabupaten Probolinggo, Propinsi Jawa Timur". Unpublished Master thesis, Graduate Program UIN Maulana Malik Ibrahim Malang, 2011.

Mujiburrahman. "Religious Conversion in Indonesia: The Karo Batak and the Tengger Javanese." Islam and Christian-Muslim Relations, 12, 1 (2001), pp. 23-38.

Mulder, Neil. Inside Indonesian Society: Cultural Change in Java. Amsterdam: The Pepin Press, 1996.

Nakamura, Mitsuo. The Grescent Arises over the Banyan Tree; A Study of The Muhammadiyah Movement in a Central Javanese Town. Yogyakarta: Gadjah Mada University Press, 1993.

Nurcahyono, Okta Hadi, "Social Capital of Indigenous Village Communities in Maintaining Social Harmony; Case Study of The Tenggerese Indigenous Community, Tosari, Pasuruan East Java." Advances in Social Science, Education, and Humanities Research (ASSEHR), Volume 313, International Conference on Rural Studies in Asia (ICoRSIA 2018).

Peacock James L. Muslim Puritans: Reformist Psychology in South-east Asian Islam. Berkeley: University of California Press, 1978.

Putri Indah Kurniasari et al. "Potret Sistem Perkawinan Masyarakat Tengger di Tengah Modernitas Industri Pariwisata." Jurnal Solidarity, 1, 1 (2012), pp. 1-4.

Ricklefs, M.C. Sejarab Indonesia Modern, trans. Dharmono Hardjowidjono. Yogyakarta: Gadjah Mada Universiry Press, 1990.

Rokhmad, Abu and Sulistiyono Susilo. "Conceptualizing Authority of the Legalization of Indonesian Women's Rights in Islamic Family Law." Journal of Indonesian Islam, 11, 2 (2017), pp. 489-508.

Soekanto, Soerjono. Kedudukan dan Peran Hukum Adat di Indonesia. Jakarta: Kurnia Esa, 1981. 
Suny, Ismail. Hukum Islam dalam Hukum Nasional. Jakarta: Universitas Muhammadiyah, 1987.

Suyitno. Mengenal Masyarakat Tradisional, Masyarakat Suku Tengger. Malang: SIC Group, 2001.

Suyono, Capt. R. P. Mistisisme Tengger. Yogyakarta: LKiS, 2009.

Thalib, Sayuti. Receptio A Contrario. Jakarta: Bina Aksara, 1980.

Tjandrasasmita, Uka (ed.). Sejarah Nasional Indonesia III. Jakarta: PN Balai Pustaka, 1984.

Tobroni, Faiq. "Keberhasilan Hukum Islam Menerjang Belenggu Kolonial dan Menjaga Keutuhan Nasional." UNISLA, XXXII, 72 (2009).

Van Leeuwen, MHD and Ineke Maas. "Endogamy and Social Class in History: An Overview." International Review of Social History, 50, S13 (2005), pp. 1-23.

Wahid, Abdurrahman. "Pribumisasi Islam." Muntaha Azhari and Abdul Mun'im Saleh (eds). Islam Menatap Masa Depan. Jakarta: P3M, 1989.

Wahyudi, Luqman. "Pendidikan Multikultural di Masyarakat Tengger Tosari Pasuruan; Studi Gerakan Pencerahan Muhammadiyah Tosari Pasuruan." Adabiyah Jurnal Pendidikan Islam, 2, 1 (2017), pp. 121-134.

Wakhyuningsih, Sri. "Nilai-Nilai Moral pada Upacara Perkawinan Adat Walagara Masyarakat Suku Tengger di Desa Jetak Kecamatan Sukapura Kabupaten Probolinggo." Unpublished Undergraduate Thesis, Malang: Universitas Negeri Malang, 2007.

Woodward, Mark R. Islam Jawa: Kesalehan Normatif versus Kebatinan. Yogyakarta: LKiS, 1999.

\section{Interviews}

Interview with Basori Alwi (the Chairman of Syuriah MWC NU Tosari, Pasuruan), September 27, 2019.

Interview with Monali (Dukun Pengarasan of Tosari village, Pasuruan), September 26, 2019.

Interview with Riyadi (Dukun of Tosari village), September 27, 2019.

Interview with Trisno Sudigdho (Chairman of Tanfiziyah MWC NU Tosari, Pasuruan), September 26, 2019. 